\title{
高強度鉄筋コンクリート部材中の重敉継手の性状に関する研究 \\ THE BEHAVIOR OF LAP SPLICES IN HIGH-STRENGTH REINFORCED CONCRETE MEMBERS
}

\author{
角陸純一* \\ Junichi KADORIKU
}

\begin{abstract}
The behavior of lap splices in high-strength reinforced concrete beams is described.The results from 23 bending test specimens, 25 pull out test specimens without transverse reinforcement, and 42 pull out test specimens with reinforcement are presented.The main variables studied were yield strength of the main bars, concrete strength, and the lap length.The results show that that shorter lap length and higher concrete strength develop greater bond splitting strength.
\end{abstract}

Keywords:lap splices, bond, splitting, beam, test, high-strength, 重称継手, 付着, 割裂、はり, 害験, 高強度。

1. はじめに

各種鉄筋継手工法の中で、重轵手は比較的細い鉄筋 の継手として、スラブ筋や壁筋等に主に用いられてきた が、鉄筋先組み工法の採用や構造物の大型化, 高層化に 伴い、より高強度かっ太径鉄筋の継手として、経済性， 施工性に優れた重ね継手を使用しようという要望が高く なっている。重ね継手は鉄筋とコンクリートとの付着を 利用して継手としての一体化を図るメカニズムであり、 その継手性能は継手部周囲のコンクリートを含めた種々 の要因に影響される。また、異形鉄筋に重权継手を設け た場合、継手部に大きな応力が生じると周团のかぶりコ ンクリートがぜい性的に割裂する付着割裂破壊となるこ とが多い。このような理由から構造性能面での信頼性が 低く、日本建築学会「鉄筋コンクリート構造計算規準・ 同解説」（1988年）では、D 29以上の太径鉄筋での重ね 継手の使用を制限している。また、対象としている設計 規準強度の上限としては、コンクリートに関しては 360 $\mathrm{kg} f / \mathrm{cm}^{2} 、$ 鉄筋に関しては SD390であり、より強度の高い 高強度鉄筋コンクリート部材に重格継手を設ける場合に
は実験等によりその構造性能を確認する必要がある。

重ね継手に関する実験研究はこれまで数多く行われて いるが、そのほとんどは普通強度の材料を使用したもの であり、高強度鉄筋を使用した研究としては、国外では R. Tepferらの研究 ")、国内では SD490鉄筋を使用した田

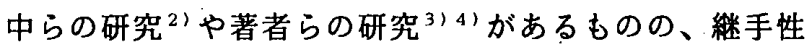
能の定量的検討は十分とは言えない。また、設計法が終 局強度設計法へと移行しつうある現在、重ね継手の設計 においては付着割裂強度の評価が重要と考えられる。

そこで、本研究では鉄筋強度（降伏点）で $7000 \mathrm{~kg} / \mathrm{cm}$ コンクリート強度で $800 \mathrm{~kg} f / \mathrm{cm}^{2}$ 程度までの高強度鉄筋コ ンクリート部材を対象として、引張り応力場での重ね継 手性状を検討した。重ね継手の性状は種々の要因の影響 を受けるが、本論文ではこれらの要因の中で材料強度と 重ね長さを主な検討パラメータとし、重ね継手を有する 高強度鉄筋コンクリート部材の変形性能やひびわれ性状 付着応力性状等へのそれらの影響を明らかにするととも に、付着割裂強度へのそれらの影響を定量的に検討した 結果について述べる。 


\section{2. 実験概要}

本研究では、曲げ部材全体としての構造特性を検討す るための曲げ実験と、主に付着割裂強度への各種要因の 影響を定量的に検討するための両引実験を行った。両引 実験は重ね継手部のみを取り出した形状の試験体を用い て直接継手筋を両引きする実験方法である。従って、部 材としての変形性能等の評価は困難であるが、試験体が 小さく実験も簡便であるため数多くのパラメー夕実験が 行えることと、付着割裂強度の評価に関しては曲げ実験 結果に比べ若干小さめになるもののほぼ同等に評価でき るものと考えられる ことから、曲げ実験に加え両引実 験を採用した。

2. 1 曲げ実験（PBシリーズ）

図ー 1 に代表的な試験体の配筋図を示すが、引張側主 筋にはD 19波ふし筋を、王縮側主筋及びスターラップ筋

表 - 1 曲げ実験試験体パラメータと実験結果一覧

\begin{tabular}{|c|c|c|c|c|c|c|c|c|}
\hline \multirow{2}{*}{$\begin{array}{l}\text { 試験体 } \\
\text { 記 号 }\end{array}$} & \multicolumn{3}{|c|}{ パラメータ・1 } & \multicolumn{5}{|c|}{ 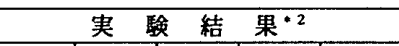 } \\
\hline & \begin{tabular}{c|}
$\mathrm{f} y$ \\
$\mathrm{~kg} f / \mathrm{cin}^{3}$
\end{tabular} & 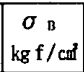 & L: & $\begin{array}{r}\mathrm{M}_{\mathrm{c}} \\
\mathrm{t}\end{array}$ & $\begin{array}{c}\mathrm{M}_{\mathrm{s}} \\
\mathrm{tan}\end{array}$ & $\begin{array}{c}M_{1} \\
\text { t四 }\end{array}$ & $\begin{array}{c}\mathrm{f}_{\mathrm{u}^{*}} \\
\mathrm{~kg} / \mathrm{f} / \mathrm{cm}\end{array}$ & 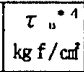 \\
\hline $\mathrm{PB}-01$ & 7224 & 628 & $20 \mathrm{~d}$ & 1.49 & 4.49 & 6.52 & 6123 & 77.1 \\
\hline $\mathrm{PB}-02$ & 7224 & 628 & $30 \mathrm{~d}$ & 1.33 & 4.20 & 7.83 & 7354 & $(1.22)$ \\
\hline $\mathrm{PB}-03$ & 7224 & 628 & $40 \mathrm{~d}$ & 1.27 & 3.81 & 7.57 & 7100 & - \\
\hline & 7224 & 228 & $30 \mathrm{~d}$ & 0.76 & 4.17 & 4.74 & 4452 & 37.4 \\
\hline & 224 & 228 & $40 \mathrm{~d}$ & 1.15 & 4.16 & 6.07 & 5701 & 35.9 \\
\hline & 224 & 228 & $50 \mathrm{~d}$ & 1.14 & 4.51 & 7.93 & 7448 & 37.5 \\
\hline & 224 & 028 & 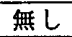 & 1.31 & 2.64 & 8.30 & 7795 & - \\
\hline $\mathrm{PB}-08$ & 7224 & 228 & 無し & 0.95 & 2.66 & 8.24 & 7739 & - \\
\hline $\mathrm{PB}-15$ & 7398 & 772 & $30 \mathrm{~d}$ & 1.32 & 4.04 & 8.46 & 7945 & $(1.46$ \\
\hline $\mathrm{PB}-16$ & 6690 & 621 & $30 \mathrm{~d}$ & 1.89 & 4.17 & 7.14 & 6706 & $(1.10)$ \\
\hline $\mathrm{PB}-17$ & 5413 & 621 & $30 \mathrm{~d}$ & 1.48 & 3.60 & 6.56 & 6156 & $(5.29)$ \\
\hline & 4512 & 21 & $30 \mathrm{~d}$ & 1.48 & 2.62 & 5.56 & 5222 & $(10.1)$ \\
\hline & 98 & 17 & $30 \mathrm{~d}$ & 1.13 & 3.23 & 6.53 & 6131 & 51.5 \\
\hline & 413 & 287 & $30 \mathrm{~d}$ & 1.33 & 3.80 & 6.00 & 5635 & 47.3 \\
\hline & 5413 & 287 & $20 \mathrm{~d}$ & 1.48 & 3.98 & 4.48 & 4207 & 53.0 \\
\hline $\mathrm{PB}-22$ & 5413 & 287 & $40 \mathrm{~d}$ & 0.95 & 3.81 & 6.35 & 5964 & $(3.89$ \\
\hline $\mathrm{PB}-23$ & 5413 & 210 & $30 \mathrm{~d}$ & 1.15 & 2.49 & 4. 18 & 3926 & 33.0 \\
\hline$P B-24$ & 4512 & 216 & $30 \mathrm{~d}$ & 1.07 & 3.42 & 4.48 & 4207 & 35.3 \\
\hline $\mathrm{PB}-25$ & 4512 & 216 & $20 \mathrm{~d}$ & & 2.77 & 3.31 & 3109 & 39.1 \\
\hline $\mathrm{PB}-26$ & 4512 & 216 & 無し & 0.95 & 4.47 & 5.08 & 4771 & - \\
\hline $\mathrm{PB}-30$ & 5413 & 287 & 無し & 1.33 & 2.66 & 6.18 & 5799 & - \\
\hline $\mathrm{PB}-31$ & 5413 & 621 & $20 \mathrm{~d}$ & 1.35 & 3.56 & 5.69 & 5344 & 67.3 \\
\hline $\mathrm{PB}-32$ & 5413 & 621 & $40 \mathrm{~d}$ & 1.49 & 3.39 & 6.55 & 6156 & - \\
\hline
\end{tabular}

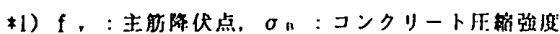

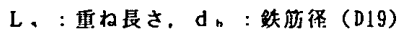

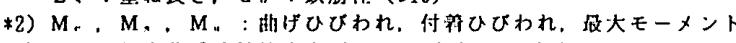

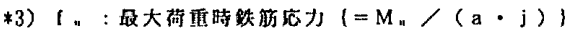

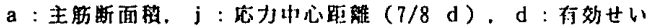

*4) $\tau_{n}=f_{n} \cdot a /\left(\phi \cdot L_{V}\right), \phi:$ 跌 $_{3}$ 周展

ただ、加っこの数体は盟性事 $(\delta, / \delta$,

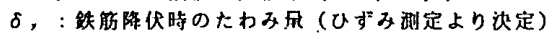

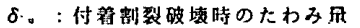

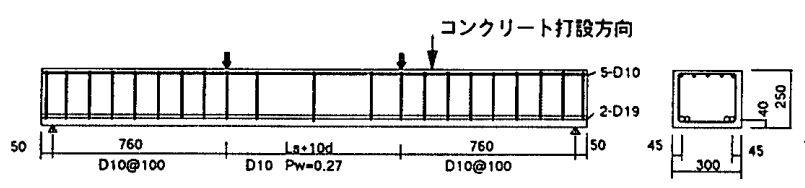

810 95 重加感鬲

B10

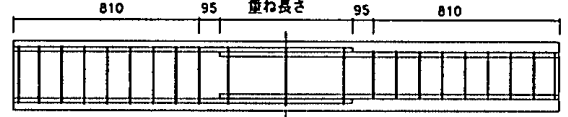

図-1 曲げ実験試験体配筋図
にはD 10波ふし筋（SD345）を用い、スターラップ筋量は 純曲げ部で 0.28 とした。なお、D 19 鉄筋で降伏点が5413 $\mathrm{kgf} / \mathrm{cm}^{3}$ 以上のものは熱処理により強度を高めた。試験体 は corner split型の付着割裂破壊を想定し、主筇の表面 かぶり厚さを約 $1.5 \mathrm{~d}$ 。（ $\mathrm{d}_{\mathrm{b}}$ : 鉄筋径）、側颛かぶり 厚さを $1.9 \mathrm{~d}$ 。、主筋ピッチを $11.0 \mathrm{~d}$ 。とした。コンク リートは継手筋が下になるように平打ちで打設した。検 討要因は、鉄筋強度、コンクリート強度、重ね長さ、継 手の有無であり、試験体一覧を表ー 1 に示す。

加力は、継手が一定曲げモーメント部にあり、かつ引 張力のみを受けるように、片側絽り返しで 2 点集中載荷 を行った。荷重蕧歴は曲げモーメント $\mathrm{M}=1.5 \mathrm{tm}, 3.0 \mathrm{tm}$, 4. 5 tmで 3 回、铁筋の降伏後は降伏時たわみ量の 1.0 , 2.0５.0倍のたわみ量で 3 回づつの繰り返しとした。

\section{2 両引実跧 1 （HTシリーズ）}

横補強筋の無い場合での重ね継手強度を検討したもの で、図ー2に代表的な試験体図を示す。主筋には曲げ試 験体と同じD 19鉄筋を用い、v notch split 破攧を想定 し、表面かぶり厚さを $1.5 \mathrm{~d}$ 。、側面かぶり厚さを 5.0 $\mathrm{d}_{\mathrm{b}}$ 、铁筋ピッチを $10.5 \mathrm{~d}$ bとした。コンクリートは継 手筋が下となるように平打ちで打設した。検討した要因 は鉄筋強度、コン.クリート強度、重ね長さであり、試験 体一覧を表一2に示す。

加力は試験体から出た鉄筋をセンターホールジャッキ

表 -2 両引実験 I 試験体パラメータと結果一覧

\begin{tabular}{|c|c|c|c|c|c|c|c|}
\hline \multirow{2}{*}{$\begin{array}{l}\text { 試験体 } \\
\text { 記 号 }\end{array}$} & \multicolumn{3}{|c|}{ パラメータ } & \multicolumn{2}{|c|}{ 実 験 } & \multicolumn{2}{|c|}{ 結 舀・1 } \\
\hline & $\begin{array}{c}\sigma_{y} \\
\mathrm{~kg} f / \mathrm{cm}^{\circ}\end{array}$ & $\begin{array}{c}\sigma_{\mathrm{B}} \\
\mathrm{kg} / \mathrm{cm}\end{array}$ & $\begin{array}{c}\mathrm{L}_{\mathrm{s}} \\
\mathrm{mm}\end{array}$ & $\begin{array}{c}\mathrm{f} \text { c } \\
\mathrm{kg} \mathrm{f} / \mathrm{cos}^{2}\end{array}$ & $\begin{array}{c}\mathbf{f} s \\
\mathrm{~kg} f / \mathrm{cm}^{\circ}\end{array}$ & \begin{tabular}{|c|}
$\mathrm{f}_{\mathrm{u}}$ \\
$\mathrm{kg} \mathrm{f} / \mathrm{cal}^{\mathrm{s}}$
\end{tabular} & $\begin{array}{c}\tau_{\mathrm{u}} \\
\mathrm{kg} \mathrm{f} / \mathrm{cm}\end{array}$ \\
\hline$T-01$ & 3960 & 228 & $25 \mathrm{~d}$ & 1007 & 2272 & 3007 & 30.3 \\
\hline & 5413 & 28 & 58 & 997 & 2014 & 3017 & 30.4 \\
\hline & 690 & & 5 & 882 & 2003 & 2913 & 29.3 \\
\hline $\mathrm{HT}-04$ & 7224 & 228 & $25 \mathrm{~d}$ & 530 & 1411 & 2620 & 26.4 \\
\hline & 9950 & 228 & $25 \mathrm{~d}$ & 1362 & 1749 & 3296 & 33.2 \\
\hline & 3960 & 594 & $25 \mathrm{~d}$ & 1418 & 3003 & 4244 & (5.58 \\
\hline & 413 & 594 & $25 \mathrm{~d}$ & 1369 & 3010 & 3986 & 40.1 \\
\hline & 690 & 594 & $25 \mathrm{~d}$ & 683 & 2610 & 4327 & 43.6 \\
\hline & 7224 & 594 & $25 \mathrm{~d}$ & 857 & 3007 & 4150 & 41.8 \\
\hline & 50 & 994 & $25 \mathrm{~d}$ & 383 & 3003 & 3997 & 40.2 \\
\hline & 3960 & 437 & $25 \mathrm{~d}$ & 1003 & 2007 & 3519 & 35.4 \\
\hline-12 & 3960 & 628 & $25 \mathrm{~d}$ & 1261 & 2617 & 4010 & (1.16 \\
\hline-13 & 5413 & 437 & $25 \mathrm{~d}$ & 1213 & 2770 & 3460 & 34.8 \\
\hline & 413 & 62 & 25 & 993 & 1972 & 3571 & 36.0 \\
\hline & 690 & 437 & $25 \mathrm{~d}$ & 1014 & 2815 & 3582 & 36.1 \\
\hline & 690 & 628 & $25 \mathrm{~d}$ & 1000 & 2003 & 3512 & 35.4 \\
\hline HT -21 & 7224 & 628 & $30 \mathrm{~d}$ & 1003 & 2484 & 4307 & 36.1 \\
\hline $\mathrm{HT}-22$ & 7224 & 628 & $40 \mathrm{~d}$ & 1213 & 2017 & 5631 & 35.4 \\
\hline & 7398 & 216 & $30 \mathrm{~d}$ & 801 & 1411 & 3007 & 25.2 \\
\hline & 7398 & 216 & $40 \mathrm{~d}$ & 1226 & 2000 & 4307 & 27.1 \\
\hline HT -25 & 7398 & 287 & $30 \mathrm{~d}$ & 1387 & 2007 & 4041 & 33.9 \\
\hline & 7398 & 287 & $40 \mathrm{~d}$ & 1585 & 2265 & 4990 & 31.4 \\
\hline & 7398 & 772 & $25 \mathrm{~d}$ & 1571 & 1742 & 4401 & 44.3 \\
\hline & 7398 & 772 & $30 \mathrm{~d}$ & 1390 & 1885 & 4603 & 38.6 \\
\hline $\mathrm{BT}-29$ & 7398 & 772 & $40 \mathrm{~d}$ & 1220 & 1220 & 5812 & 36.6 \\
\hline
\end{tabular}

*1) f c . f , : 引張，付着ひびわれ発生時制筋応》 
を用いて両側から絽り返し引張る載荷を行った。荷重嘚 歴は、鉄筋応力 $\mathrm{f}_{\mathrm{t}}=1000,2000,3000 \mathrm{kgf} / \mathrm{cm}^{2}$ で 3 回、鉄 筋降伏後は降伏時変形の 1.0 .2 .0 .5 .0 倍の検長間変形で 3 回づつの繰り返しとした。

2. 3 両引実験 2 （STシリーズ）

横補強筋を有する場合での重ね継手強度を検討したも ので、図ー3に代表的な試験体図を示す。全試験体とも 主筋の降伏前に付着割裂破壊をさせるべく、主筋には熱 处理により強度を高めたD 19鉄筋（ $\sigma_{y}=8600 \mathrm{~kg} \mathrm{f} / \mathrm{cm}^{2}$, 0.2\%酎力）を用い、corner split型の破壊を想定し、表 面と側面かぶり厚さを $1.5 \mathrm{~d}$ 。、鉄筋ピッチを $11.6 \mathrm{~d}$ 。 とし、継手部の補強筋量を0.2xとした。コンクリートは $\mathrm{b} \times \mathrm{D}=30 \times 20 \mathrm{~cm}$ の試験体については継手筋が下となる ように平打ちで打設した。検討した要因は、コンクリー 卜強度、重㛊長さ、継手位置（上下端筋）であり、表一

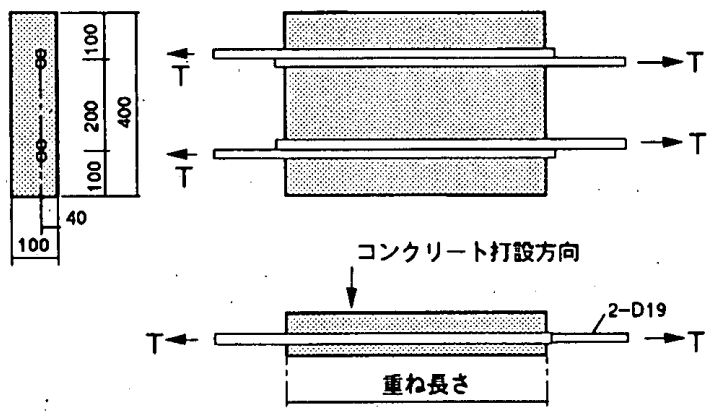

図 -2 両引実験 I 試験体図
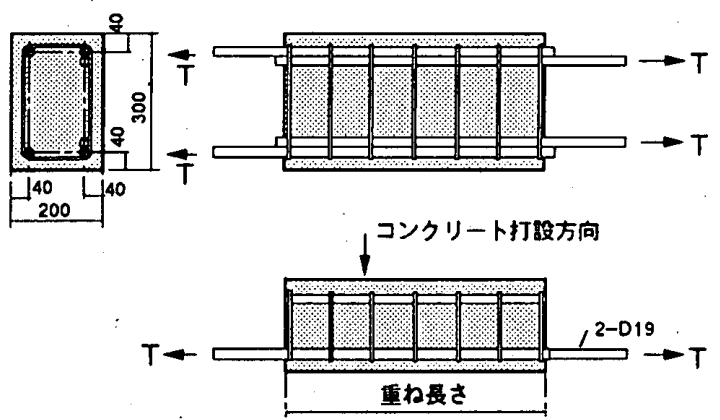

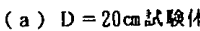

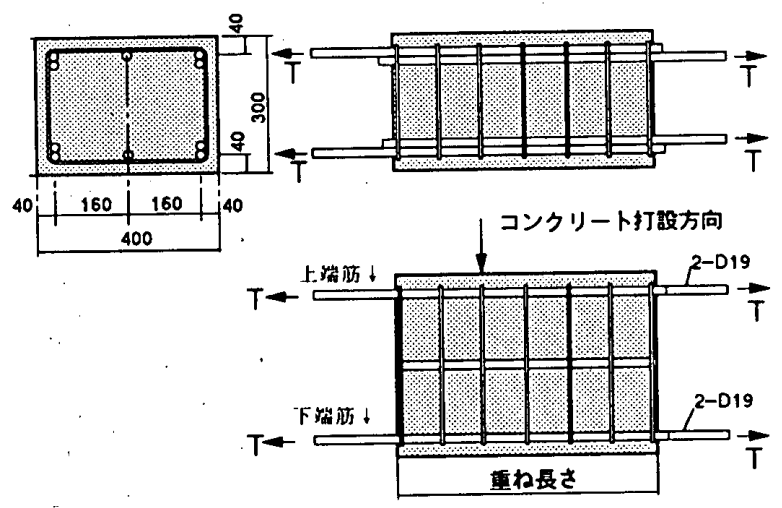

(b) $D=40 \mathrm{cos}$ 蛅路体

図 -3 両引実験 II 試験体図
3に式臨体一覧を示す。

加力は両引実験 1 と同じ方法により、 $\mathrm{f}_{\mathrm{t}} \mathrm{t}^{2}=2200,3500$ $5000,7000 \mathrm{kgf} / \mathrm{cmil}^{2}$ で 3 回づつの繰り返し載荷を行った。

表 -3 両引実験 II 試験体パラメータと結果一覧

\begin{tabular}{|c|c|c|c|c|c|c|c|}
\hline \multirow{2}{*}{$\begin{array}{l}\text { 試験体 } \\
\text { 記 号 }\end{array}$} & \multicolumn{3}{|c|}{ パラメータ } & \multicolumn{4}{|c|}{ 実 験 結 果 } \\
\hline & $\begin{array}{c}\sigma_{\text {в }} \\
\mathrm{kg} \mathrm{f} / \mathrm{cml}^{\prime}\end{array}$ & \begin{tabular}{|c|}
$\mathrm{L}$ \\
$\mathrm{kg} \mathrm{f} / \mathrm{cmi}$
\end{tabular} & $\begin{array}{l}\mathrm{D}^{* 2} \\
\mathrm{~cm}\end{array}$ & $\begin{array}{l}\mathrm{f} \text { c } \\
\mathrm{kg} \mathrm{f} / \mathrm{cm}\end{array}$ & $\begin{array}{c}\mathrm{f} \\
\mathrm{kg} / \mathrm{s} / \mathrm{cm}^{3}\end{array}$ & $\begin{array}{c}\mathrm{f}_{0} \\
\mathrm{~kg} \mathrm{f} / \mathrm{cmif}\end{array}$ & $\begin{array}{c}\tau_{\mathrm{u}} \\
\mathrm{kg} / / \mathrm{cm}\end{array}$ \\
\hline ST -01 & 279 & $5 \mathrm{dt}$ & 20 & - & - & 662 & 33.3 \\
\hline ST -02 & 279 & $10 \mathrm{~d}$ & 20 & - & - & 1394 & 35.1 \\
\hline ST -03 & 279 & $15 \mathrm{~d}$ & 20 & - & - & 2230 & 37.4 \\
\hline ST -04 & 279 & $30 \mathrm{~d}$ & 20 & 1777 & 3171 & 3937 & 33.0 \\
\hline ST -05 & 279 & $40 \mathrm{~d}$ & 20 & 1812 & 3171 & 4878 & 30.7 \\
\hline \multirow{2}{*}{$\mathrm{ST}-06 \mathrm{y}$} & \multirow[t]{2}{*}{279} & \multirow[t]{2}{*}{$10 \mathrm{~d}_{\mathrm{b}}$} & \multirow[t]{2}{*}{40} & - & - & 1742 & 43.9 \\
\hline & & & & - & - & 1394 & 35.1 \\
\hline \multirow{2}{*}{ ST $-07 \mathrm{Y}$} & \multirow[t]{2}{*}{279} & \multirow[t]{2}{*}{$20 \mathrm{~d}$} & \multirow[t]{2}{*}{40} & - & 2125 & 2578 & 32.5 \\
\hline & & & & - & 2230 & 3310 & 41.7 \\
\hline \multirow{2}{*}{ ST $-08 \mathrm{y}$} & \multirow[t]{2}{*}{279} & \multirow[t]{2}{*}{$30 \mathrm{~d}$} & \multirow[t]{2}{*}{40} & 1777 & 3519 & 4077 & 34.2 \\
\hline & & & & 2230 & 2230 & 4669 & 39.2 \\
\hline \multirow{2}{*}{ ST-09y } & \multirow[t]{2}{*}{279} & \multirow[t]{2}{*}{$40 \mathrm{~d}$} & 40 & 2230 & 2822 & 4704 & 29.6 \\
\hline & & & & 1951 & 2230 & 6063 & 38.2 \\
\hline ST -10 & 499 & $20 \mathrm{~d}$ & 20 & 1080 & 2822 & 4530 & 57.0 \\
\hline $\mathrm{ST}-11$ & 499 & $30 \mathrm{~d}$ & 20 & 1115 & 2265 & 6934 & 58.2 \\
\hline $\mathrm{ST}-12$ & 499 & $40 \mathrm{~d}$ & 20 & 1394 & 2822 & 9059 & 57.0 \\
\hline ST -13 & 688 & $20 \mathrm{~d}$ & 20 & 1812 & 2230 & 5052 & 63.6 \\
\hline ST -14 & 688 & $30 \mathrm{~d}$ & 20 & 1394 & 2822 & 7038 & 59.1 \\
\hline $\mathrm{ST}-15$ & 688 & $40 \mathrm{~d}$ & 20 & 1394 & 3519 & 9338 & 58.8 \\
\hline $\mathrm{ST}-16$ & 497 & $20 \mathrm{~d}$ & 20 & 1777 & 2787 & 4460 & 56.1 \\
\hline $\mathrm{ST}-17$ & 497 & $30 \mathrm{~d}$ & 20 & 1742 & 3484 & 6690 & 56.1 \\
\hline ST -18 & 497 & $40 \mathrm{~d}$ & 20 & 1777 & 2822 & 8502 & 53.5 \\
\hline $\mathrm{ST}-19$ & 835 & $20 \mathrm{~d}$ & 20 & 2230 & 2230 & 5052 & 63.6 \\
\hline $\mathrm{ST}-20$ & 835 & $30 \mathrm{~d}$ & 20 & 1777 & 2822 & 7840 & 65.8 \\
\hline $\mathrm{ST}-21$ & 835 & $40 \mathrm{~d}$ & 20 & 1429 & 2265 & 9443 & - \\
\hline ST -22 & 631 & $20 \mathrm{~d}$ & 20 & 1777 & 2787 & 5017 & 63.2 \\
\hline $\mathrm{ST}-23$ & 631 & $30 \mathrm{~d}$ & 20 & 1429 & 2822 & 7143 & 59.9 \\
\hline $\mathrm{ST}-24$ & 631 & $40 \mathrm{~d}$ & 20 & 1080 & 2195 & 9408 & 59.2 \\
\hline ST -25 & 579 & $5 \mathrm{~d}$ & 20 & - & - & 976 & 49.1 \\
\hline $\mathrm{ST}-26$ & 579 & $10 \mathrm{~d}$ & 20 & - & - & 2021 & 50.9 \\
\hline $\mathrm{ST}-27$ & 579 & $15 \mathrm{~d}$ & 20 & - & 2787 & 3136 & 52.6 \\
\hline ST -28 & 579 & $20 \mathrm{~d}$ & 20 & 2125 & 2822 & 3868 & 48.7 \\
\hline ST -29 & 579 & $30 \mathrm{~d}$ & 20 & 1777 & 2265 & 5052 & 42.4 \\
\hline $\mathrm{ST}-30$ & 579 & $40 \mathrm{~d}$ & 20 & 1777 & 2230 & 6690 & 42.1 \\
\hline$S T-314$ & 579 & $10 \mathrm{~d}$ & 40 & - & - & 2160 & 54.4 \\
\hline & & & & - & $-_{c}$ & 2230 & 56.1 \\
\hline ST $-32 u$ & 579 & $20 d$ & 40 & 2230 & 2787 & 3833 & 48.2 \\
\hline & & & & 2822 & 3519 & 4669 & 58.8 \\
\hline$S T-33 \mathrm{U}$ & 579 & $30 \mathrm{~d}$ & 40 & 2230 & 2822 & 5436 & 45.6 \\
\hline & & & & 1777 & 2195 & 6446 & 54.1 \\
\hline$S T-34 \mathrm{U}$ & 579 & $40 \mathrm{~d}$ & 40 & 2091 & 3519 & 6794 & 42.8 \\
\hline & & & & 2230 & 2822 & 8641 & 54.4 \\
\hline $\mathrm{ST}-35$ & 663 & 50 & 20 & - & - & 1080 & 54.4 \\
\hline $\mathrm{ST}-36$ & 663 & $10 \mathrm{~d}$ & 20 & 2230 & 2230 & 2439 & 61.4 \\
\hline ST -37 & 663 & $15 \mathrm{~d}$ & 20 & 1777 & 2230 & 3554 & 59.6 \\
\hline $\mathrm{ST}-38$ & 663 & $20 \mathrm{~d}$ & 20 & 1812 & 2265 & 3693 & 46.5 \\
\hline ST -39 & 663 & $30 \mathrm{~d}$ & 20 & 2230 & 2230 & 5923 & 49.7 \\
\hline $\mathrm{ST}-40$ & 663 & $40 \mathrm{~d}$ & 20 & 1429 & 3519 & 9268 & 58.3 \\
\hline ST $-41 \mathrm{U}$ & 663 & $20 \mathrm{~d}$ & 40 & 2230 & 1777 & 4111 & 51.8 \\
\hline & & & & 1777 & 2265 & 5052 & 63.6 \\
\hline & 663 & $30 \mathrm{~d}$ & 40 & 2265 & 2265 & 5819 & 48.8 \\
\hline & & & & 1777 & 2822 & 7317 & 61.4 \\
\hline
\end{tabular}

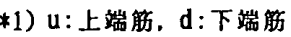

*2）D：はりせい 


\section{3. 実験結果}

3. 1 曲げ実験（PBシリーズ）

表ー 1 に曲げ実験の諸結果一覧を示す。図ー 4 に荷重 一変形関係の 1 例としてPB-02試験体の荷重一たわみ量 曲線を、図ー 5 にひびわれ発生状況の 1 例を示す。破壊

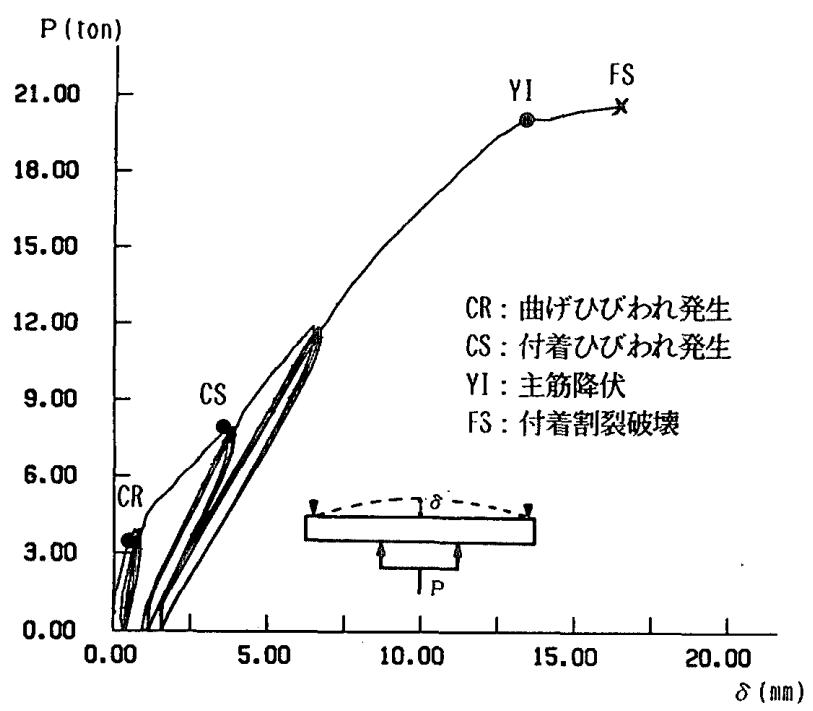

図-4 荷重一たわみ量関係 $(\mathrm{PB}-02)$

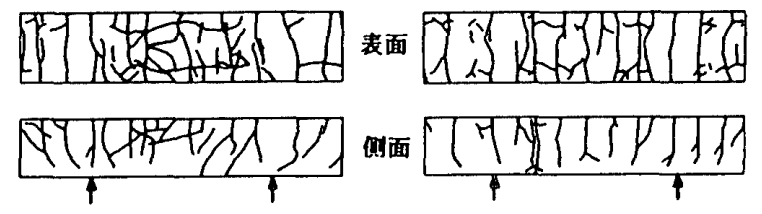

(a) 期予行り出确体

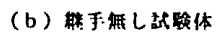

図一 5 曲げ実験ひびわれ性状

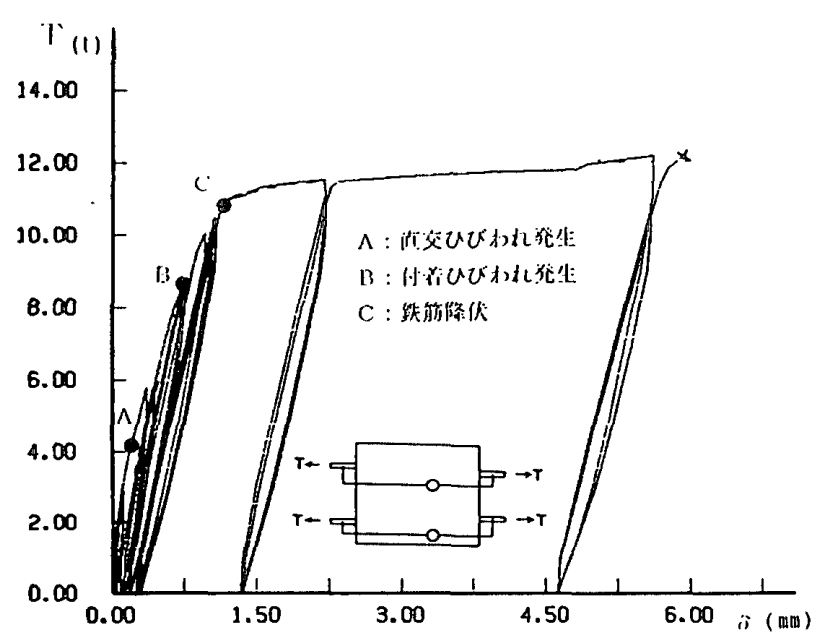

図-6 鉄筋引張力一検長間伸び量関係 $(H T-06)$

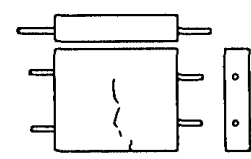

(a) $T=2.9$ ton

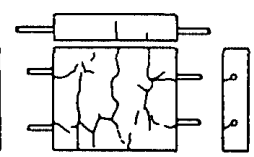

(b) $T=8.6$ ton

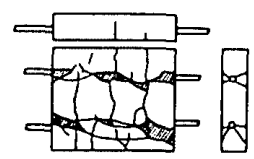

(c) 挭域脂
図-7 両引実験 I ひびわれ性状（HT-06）
経過はいずれの試験体も主筋に直交する曲げひびわれが 発生した後、主筋に沿う付着ひびわれが継手端部より発 生し、徐々に継手中央部へと進展し、コンクリートの圧 壊で破壊した 6 体（PB-03.07, 08, 26,30，32）除いて、 継手部のかぶりコンクリートが主筋に治って割裂し急激 に耐力が低下する付着割裂により破壊した。これらの中 で 7 体は鉄筋降伏後変形が増大した後の付着割裂破罗で あった。降伏前に割裂破壊した試験体については付着割 裂強度として表中に継手全体の平均付着応力度を示して いるが、降伏後付着割裂破壊を生じた試験体については 最大たわみ量を降伏時のたわみ量で除した塑性率を示し ている。付着割裂破壊の形式は、隅角部のかぶりコンク リートが割裂するcorner split型破壊であった。

3. 2 両引実験 1 (HTシリーズ)

表ー 2 に両引実験 1 の諸結果一覧を示す。図一 6 に荷 重一変形関保の 1 例としてHTー06試験体の鉄筋引張力ー 検長間伸び量曲線を、図ー7にひびわれ発生状沿の 1 例 を示す。破壊経過は曲げ式験体の場合と同様で、2 体が 鉄筋降伏後の付着割裂破塤となった以外は、すべて鉄筋 降伏前の付着割裂破壊であった。いずれの試験体も破填 形式は、表面のかぶりコンクリートが割裂するv notch split 型の破壊であった。

3. 3 両引実験 2 (STシリーズ)

表 -3 に両引実験 2 の諸結果一覽を示す。図-8 8 に荷 重一变形関係の 1 例としてST-24試験体の鉄筋引張力一 検長間伸び量曲線を、図ー9にひびわれ発生状沉の 1 例 を示す。破壊経過は曲げ試験体の場合と同様で、破壊せ

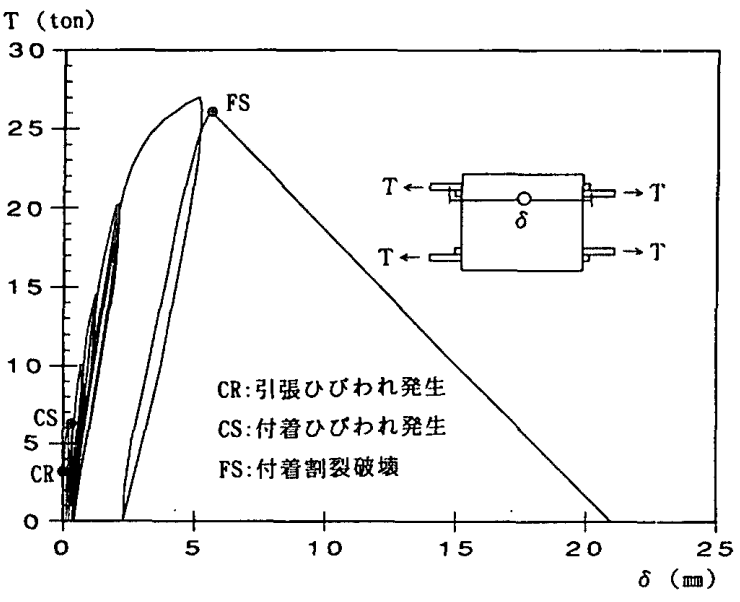

図-8 鉄筋引張力 一検長間伸び量関係 $(\mathrm{ST}-24)$

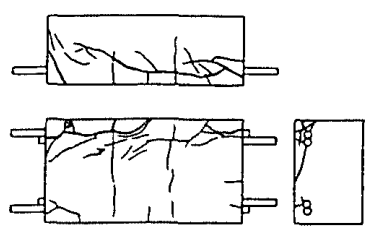

(a) $\sigma_{11}=279 \mathrm{~kg} / \mathrm{cull}$

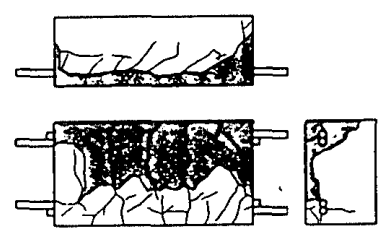

(b) $\sigma_{11}=835 \mathrm{~kg} / / \mathrm{cal}$
図-9 両引実験 IIひびわれ性状（ST-24） 
ずに実験を終了したSTー21試験体を除いてすべて鉄筋降 伏前の付着割裂破壊であった。破壊形式は、隅角部のか ぶりコンクリートが割裂する corner split型の破壊であ ったが、コンクリート強度が高い試験体や重ね長さの長 い試殹体では破壊時の荷重が大きくなり、破壊状況も激 しく、かぶりコンクリートのはく落や飛散などが見られ た。

\section{4. 結果の椧討}

4. 1 重ね継手を有する部材の力学的性状

重ね継手部では鉄筋が 2 本重ね合わされており、2 の鉄筋のひずみの合計が通し筋のひずみと等しくなると 考えられる。従って、重ね継手筋のひずみは三角形分布 になると考えられるが、図ー 10 に示すように荷重が小 さい場合には継手両端部のひずみ勾配が大きく、中央部 ではほぼ一定のひずみ分布となっている。付着応力度は 鉄筋表面の単位面積当りに生じる面内応力で表されるの で、ある区間の鉄筋ひずみの差、つまり、ひずみ勾配に 対応することになる。従って、付着応力度分布は荷重が 小さいレベルでは継手中央部がほとんど.0である凹形状 となる。しかしながら、荷重の増加に伴い中央部のひず
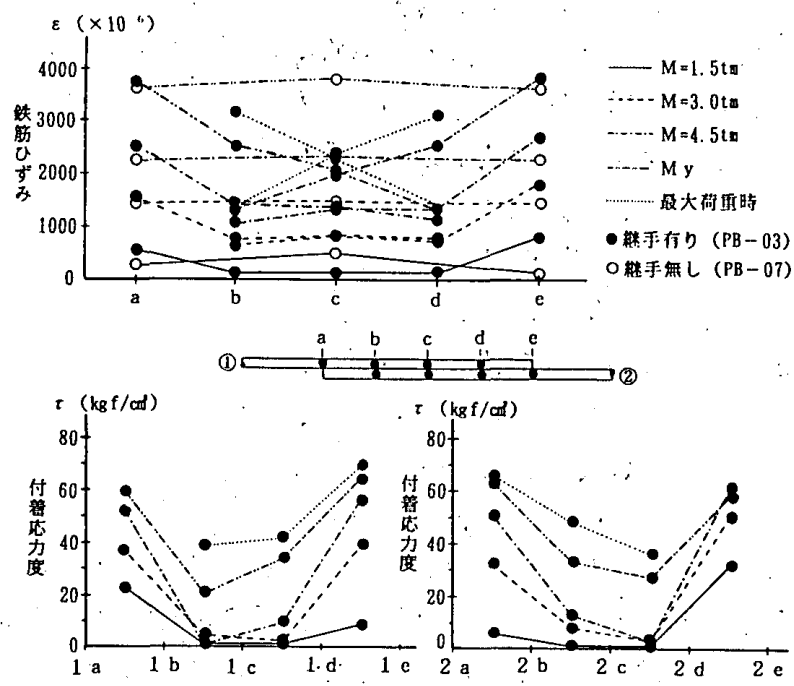

図一-10 継手筋のひずみと付着応力度分布
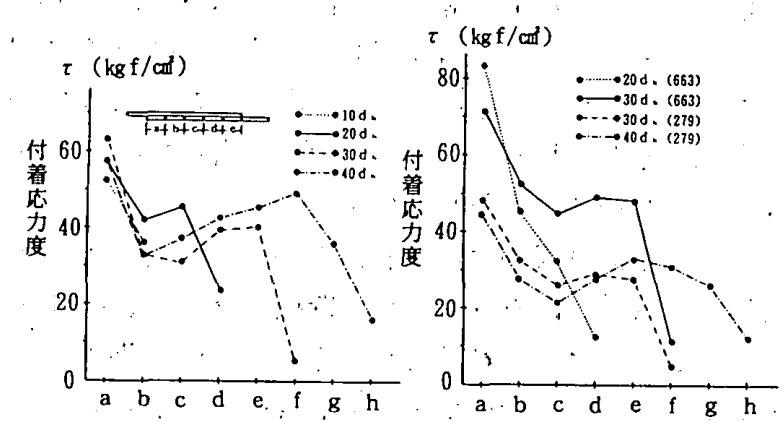

(a) STシリース

(b) $P B$ シリ $-x$

図-11 最大荷重時の付着灾力度分布比較
みが增加し、破壊直前には継手部全体でほぼ一定のひず み勾配となる。主筋が降伏する試験体でも継手中央部の ひずみは増加しており、この結果、鉄筋降伏後においで も付着割裂破壊が起こりうることがわかる。付着蚛力度 分布は破壊直前には継手部全体でほぼ一定の分布になっ ており、栍手全体である限界の付着応力度に達した時、 付着割裂破壊が引き起こされものと考えられる。

図ー 11 には曲げ実験と両引実験ジリーズの重ね長さ の異なる試検体について、破壊直前の付着忍力度分布を 比較して示している。加力方法の違いにかかわらず、ほ ぼ同様な分布を示しており、破罱直前に一定の付着応力 度分布になるものの、詳細に見ると、いずれの重ね長さ でも荷重端部の付着応力度が逆に小さくなっており、自 由端部の付着応力度が大きくなっている。これは、継手 端部のコンクリートが局部的に破壊し、付着性能が低下 していることをあらわしていると考えられる。

図一 12 にコンクリート強度の異なる重ね長さ $30 \mathrm{~d}$ b の試験体について付着応力度比分布を示す。付着応力度 比とは継手部各测定区間の付着応力度を継手全体の平均 付着応力度で除した值である。コンクリート強度が高い と付着応力度比は継手端部で大きく中央部では小さくな っており、荷重レベルが小さい場合その㑯向が大きい。 つまり、コンクリート強度が高い場合には継手端部での 付着力の負担が大きく、その結果付着性能が向上するも

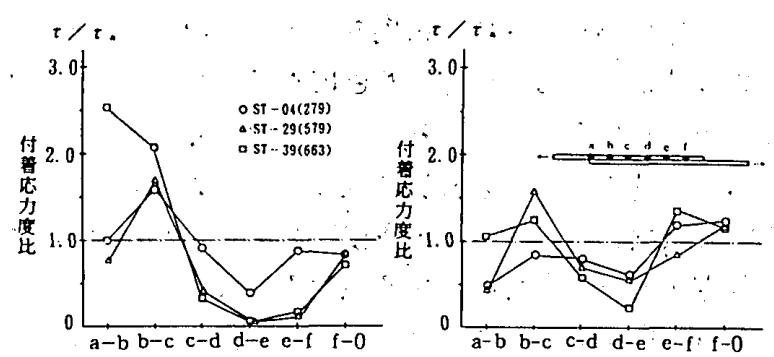

(a) $\mathrm{ft}=1000 \mathrm{~kg} / \mathrm{col}$

- (b ) $\mathrm{ft}=3500 \mathrm{~kg} / / \mathrm{cdl}$

図一12 コンクリート強度による付着応力度比の比較

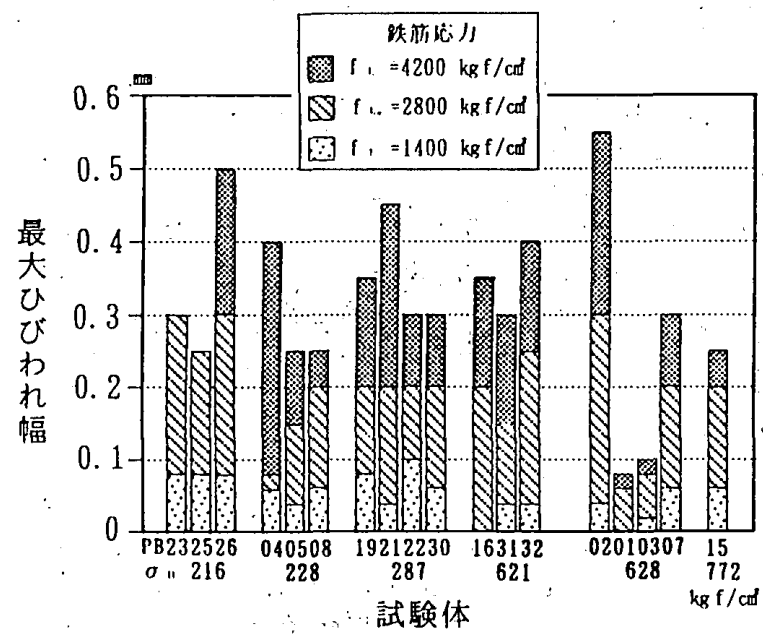

図-: 13 最大ひびわれ幅の比較 
のと考えられる。

図ー13には曲げスパン内に生じた曲げひびわれにつ いて、鉄筋応力 f t $1400,2800,4200 \mathrm{~kg} \mathrm{f} / \mathrm{cm}^{2}$ での最大ひび われ幅を比較して示している。重ね継手が無い部材では 曲げひびわれが分散するのに対し、重ね継手が有ると継 手端にひびわれが集中し、その幅が大きくなると言われ ている。実験では鉄筋の降伏後継手端のひびわれが大き く開くという性状が見られたが、弾性範囲内では継手有 無によるひびわれ幅の差異はほとんど見られなかった。 継手を有する試験体について最大ひびわれ幅を平均する と、普通強度の場合、鉄筇応力度 $1400 \mathrm{~kg} \mathrm{f} / \mathrm{cm}^{2}$ で $0.07 \mathrm{~mm}$ 、 $2800 \mathrm{~kg} \mathrm{f} / \mathrm{cm}^{2}$ で0. $20 \mathrm{~mm} 、 4200 \mathrm{~kg} \mathrm{f} / \mathrm{cm}^{2}$ で0.35m、高強度コン クリートの場合ではそれぞれ0.03 $\mathrm{mm} 、 0.18 \mathrm{~mm} 、 0.29 \mathrm{~mm}$ と なっている。これより、コンクリート強度が高いとひび われ幅が小さくなる㑯向があると言える。ただし、試験 体によりひびわれ幅のばらつきは大きい。

\section{2 付着割裂強度への各種要因の影䈏}

鉄筋降伏後付着割裂破壊した試験体は、鉄筋強度に影 響され、最大耐力がほとんど増加しなく、強度評価が困 㒕である。従って、重ね継手の付着割裂強度の検討にお いては鉄笳降伏前に付着割裂破壊した試験体の最大荷重、 時の平均付着応力度を用いる。

a . 重ね長さ

図一-14には付着割裂强度と重ね長さの関係を示して いる。図中、白黒半分記号がHTシリーズの結果を、白抜 きの記号がPBシリーズの結果を、黒淕りの記号がSTシリ 一ズの結果を示している。HTとPBシリーズの結果につい ては記号が見えにくくなるので、重ね長さ（x軸）を左 右にずらせて示している。各実験シリーズの結果とも付 着割裂強度は、コンクリート強度の違いにかかわらず重 ね長さが短いと大きく、ある程度重ね長さが長いと一定 になる項向が見られる。ただし、重ね長さ $5 \mathrm{~d}$ bの場合 の付着割裂強度はいずれのコンクリート強度でも逆に小 さくなっている。極端に重ね長さが短い試験体では、破 壊性状は付着割裂破壊というょりもむしろ引き抜き破壊

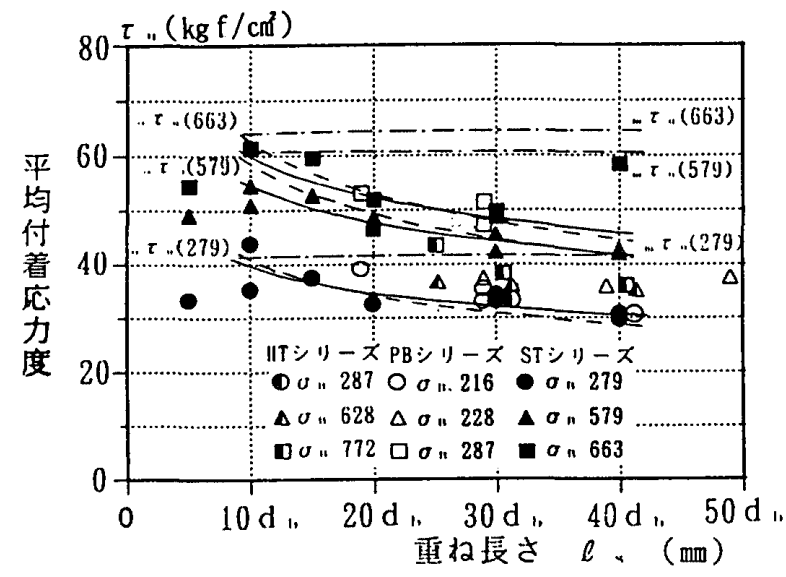

図-14 付着割裂強度一重ね長さ関係
のような割裂性状を示しており、付着割裂強度が小さく なった原亩はこの破壊性状の違いにあると思われる。テ 一夕数の多いSTシリーズの結果について、重ね長さが短 い $5 \mathrm{~d}_{\mathrm{b}}$ の試験体と、他の試験体に比へ極端に大きな付 着割裂強度值となった ST -40試験体の結果を除いて近做 式を求めると、

$$
\begin{aligned}
& \sigma_{\mathrm{B}}=279 \text { の時 } \tau_{\mathrm{u}}=59.06\left(\ell_{\mathrm{s}} / \mathrm{d}_{\mathrm{b}}\right) \cdots 0.177 \cdots(1) \\
& \sigma_{\mathrm{B}}=579 \text { 時 } \tau_{\mathrm{u}}=79.15\left(\ell_{\mathrm{s}} / \mathrm{d}_{\mathrm{b}}\right)-0.168 \ldots(2) \\
& \sigma_{\mathrm{B}}=663 \text { 時 } \tau_{\mathrm{u}}=101.6\left(\ell_{\mathrm{s}} / \mathrm{d}_{\mathrm{b}}\right)-0.221 \ldots(3)
\end{aligned}
$$

となり、それぞれの相関係数は $0.8062 、 0.9340 、 0.8449$ となる。コンクリート強度にかかわらず重ね長さに対す る付着割裂強度の減少率は同じと考えると、実倹データ の近做式はそれぞれ下式のように表せる。

$\sigma_{\mathrm{B}}=279$ の時 $\tau_{\mathrm{u}}=61.5\left(\boldsymbol{\ell}_{\mathrm{s}} / \mathrm{d}_{\mathrm{b}}\right)^{-0.19 \ldots \ldots(4)}$

$\sigma_{\mathrm{B}}=5790$ 時 $\tau_{\mathrm{u}}=84.6\left(\ell_{\mathrm{s}} / \mathrm{d}_{\mathrm{b}}\right)^{-0.19 \cdots \cdots(5)}$

$\sigma_{\mathrm{B}}=663$ の時 $\tau_{\mathrm{u}}=92.7\left(\boldsymbol{\ell}_{\mathrm{s}} / \mathrm{d}_{\mathrm{b}}\right)^{-0.19 \ldots . .(6)}$

図中にこれらの近似式を実線で示す。また、付着割裂強 度式として提案されている Orangun式（。元u）㣙森 田・藤井式 $\left(\mathrm{m} \tau_{\mathrm{u}}\right)$ 》を用いて算定した值をそれぞれ 破線と一点鎖線で示す。なお、実験結果は後でのべるよ うに上端筋の結果に近いので、上端筋として算定した。 森田・藤井式では各コンクリート強度について次の算定 値が得られる。式中では割裂パターンの判定尺度 $\mathrm{b}_{\mathrm{i}}$ と

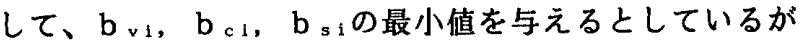
本試験体の場合は corner split 型となる $\mathrm{b}_{\mathrm{ci}}$ が最小值 となり、実際の破壊性状とも一致している。

$$
\begin{array}{ll}
{ }_{\mathrm{m}} \tau_{\mathrm{u}}(279) & =42.0 \\
{ }_{\mathrm{m}} \tau_{\mathrm{u}} & (579)=60.5 \\
{ }_{\mathrm{m}} \tau_{\mathrm{u}}(663)=64.7
\end{array}
$$

また、0rangun式では次式が得られる。

$$
\begin{aligned}
& \circ \tau_{\mathrm{u}}(279)=72.25\left(\ell_{\mathrm{s}} / \mathrm{d}_{\mathrm{b}}\right)^{-0.25} \\
& \circ \tau_{\mathrm{u}}(579)=103.49\left(\ell_{\mathrm{s}} / \mathrm{d}_{\mathrm{b}}\right)^{-0.25} \\
& \circ \tau_{\mathrm{u}}(663)=110.77\left(\ell_{\mathrm{s}} / \mathrm{d}_{\mathrm{b}}\right)^{-0.25}
\end{aligned}
$$

図より、重ね長さを考虑したOrangun 式は奏験結果と 良く一致しており、これより重ね継手の付着割裂強度の 評価には重ね長さの考虑が必要であると言える。

b 、コンクリート強度

図一 15 には横補強筋の無い試験体（HTシリーズ）に ついて、図－16には横補強筋を有する試験体（PB、ST シリーズ）について、付着割裂強度とコンクリート強度 の関係を示している。図ー16の中で白抜きの記号がPB シリーズの結果を、黒塗りの記号がSTシリーズの結果を 示している。各図中には重ね長さ $30 \mathrm{~d} 。$ の試験体につい て実験值（HT、STシリーズ）を近似した結果安実線で、 Orangun式による計算結果を破線で、森田・藤井式によ る計算結果を一点鎖線で示している。それぞれについて 実験データの近似をすると補強筋の無い場合、

$\ell_{s}=25 d_{b}$ で $\tau_{a}=5.646 \sigma_{b} 0.3059 \ldots \ldots$ (7) 
$\ell_{\mathrm{s}}=30 \mathrm{~d}_{\mathrm{b}}$ で $\tau_{\mathrm{u}}=6.536 \sigma_{\mathrm{B}} 0.2686 \ldots \ldots$ (8)

$\ell_{s}=40 \mathrm{~d}_{\mathrm{b}}$ で $\tau_{u}=8.864 \sigma_{\mathrm{B}} 0.2119 \ldots \ldots(9)$

となり、相関係数は $0.8799 、 0.8810 、 0.9686$ となる。 補強筋が有る場合は、

$\ell_{\mathrm{s}}=30 \mathrm{~d}_{\mathrm{b}}$ で $\tau_{\mathrm{u}}=2.4697 \sigma_{\mathrm{B}} 0.5259(\mathrm{~PB})$

$\ell_{\mathrm{s}}=20 \mathrm{~d}_{\mathrm{b}}$ で $\tau_{\mathrm{u}}=1.6357 \sigma_{\mathrm{B}} 0.5156(\mathrm{ST})$

$\ell_{: s}=30 \mathrm{~d}_{\mathrm{b}}$ で $\tau_{\mathrm{u}}=1.7331 \sigma_{\mathrm{B}}{ }^{0.5324}(\mathrm{ST})$

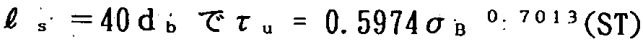

相関係数は $0.9556 、 0.7345 、 0.7880 、 0.8352$ となる。い ずれの場合も付着割裂強度はコンク!ート強度が高いほ ど大きくなるが、コンクリート強度に対する増加率は補 虫觔のある場合の方が大きくなっている。図ー15 中に は材料試験で得られたコンクリートの圧縮強度 $\sigma_{\mathrm{B}}$ と引 張強度 $\sigma_{\mathrm{t}}$ との関係を示しているが、その関係を近做す ると、引張強度は $\sigma_{\mathrm{t}}=7.126 \sigma_{\mathrm{B}}{ }^{0.63}$ と表され、横補強 筋が無い場合の付着割裂強度のコンクリートの圧縮強度 に対する増加率は引張強度の場合の増加率と比べて小さ くなっている。また同じ補強筋量の場合、PBとSTシリー ズで增加率はほぼ等しいが、付着割裂強度自体は全体的 にPBシリーズの方が大きくなっている。

既往の付着割裂強度式では補強筋量にかかわらず付着 割裂強度はコンクリート強度の平方根に比例して増加す

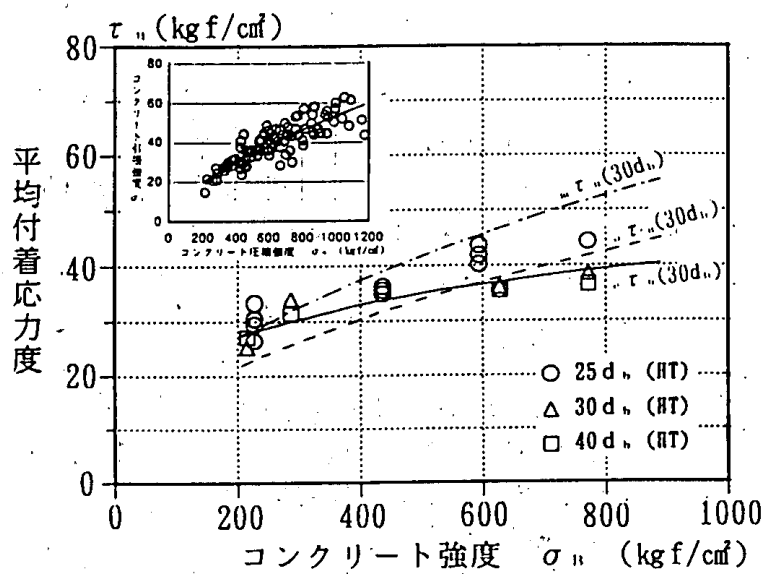

図- 15 付着割裂強度ーコンクリート強度（pw=0\%）

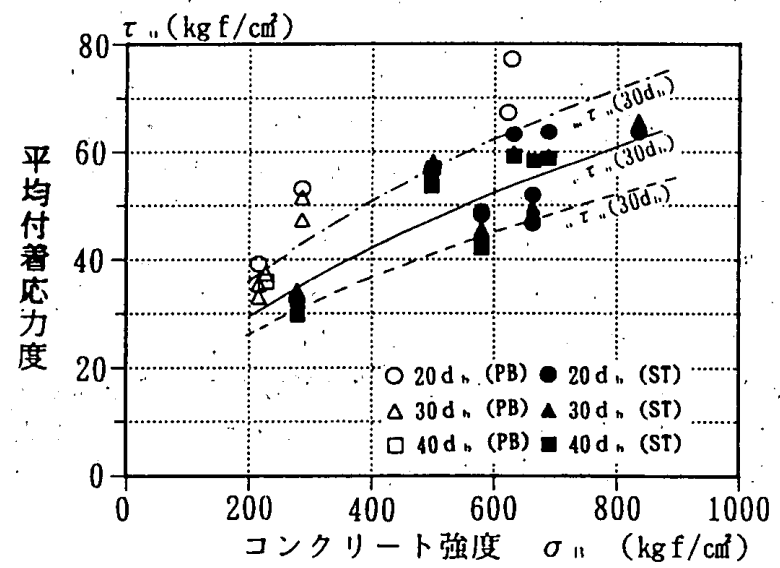

図 -1.6 付着割裂強度一コンクリート強度（ $(\mathrm{pw}=0.2 \% ）$
る形としているが、補強筋が無い場合にはより小さな增 加率 ( $\sigma_{\mathrm{B}}$ の約 0.3乗) であり、完全補強（鋼管補強な ど）の場合には付着割裂破壊が生じないと仮定すると鉄 筋表面の節とコンクリートとの支圧作用が支配的となり 付着割裂強度は $\sigma_{\mathrm{B}}$ の 1.0 乗に比例すると考えられる。 従って、高強度コンクリート中の重好継手の付着割裂強 度を評価する場合には、コンクリート強度の平方根に比 例するという考え方よりむしろ、コンクリート強度に対 する増加率自体に横補強筋量を考慮する考え万が必要之 言える。しかしながら、本実满では補強筋の有無による 影㬐を検討しただけで、補強筋量の定量的影響について は今後の課題であると言える。

\section{c. 上端筋之下端筋}

図ー 17 には重和長さとコンクリート強度の異なる試 験体について、上端筋と下端筇の付着割裂虽度を比較し て示している。図中、黒梁りの記号が下端筋、白抜きの. 記号が上端筋の結果を、また、白黒半分の記号がはりせ い20 cmの試験体の結果を示している。破壊が引き抜き破 壊的であった重ね長さ10d。の試験体では上端筋と下端 筋の付着応力度に差異はほとんど見られないが、重ね長 さ20 d b 以上の試験体では、重ね長さやコシクリート強 度の違いにかかわらず下端筋の方が大きな付着割裂強度 を示している。下端筋と上端筋の付着割裂強度の比は、 $\sigma_{\mathrm{B}}=279 \mathrm{~kg} \mathrm{f} / \mathrm{cm}^{2}$ の場合 $1.24 、 \sigma_{\mathrm{B}}=579 \mathrm{~kg} / \mathrm{cm}^{2}$ の場合 1.23 $\sigma_{\text {в }}=633 \mathrm{kgf} / \mathrm{cm}^{2}$ の場合 1.25 、また、重好長さ $\ell_{s} 20 \mathrm{~d}$ 。 の場合 $1.24 、 \ell, 30 \mathrm{~d}_{\mathrm{b}}$ の場合 $1.20 、 \ell_{\mathrm{s}} 40 \mathrm{~d}_{\mathrm{b}}$ の場合 1.28 となっており、付着割裂強度の比にコンクリート強 度や重ね長さによる差異はほとんど見られない。また、 はりせい $20 \mathrm{~cm}$ の試験体の付着割裂強度は上端筋のデータ に近い結果となった。全試験体の付着割裂強度の比を平 均すると 1.24 となる。既往の研究では上端筋と下端筋の 比を1. 22 とている ${ }^{8)}$ が、本実験結果はこれより若干大 きくなっていものの大差はないと言える。

以上より、高強度鉄筋コンクリート部材においても上

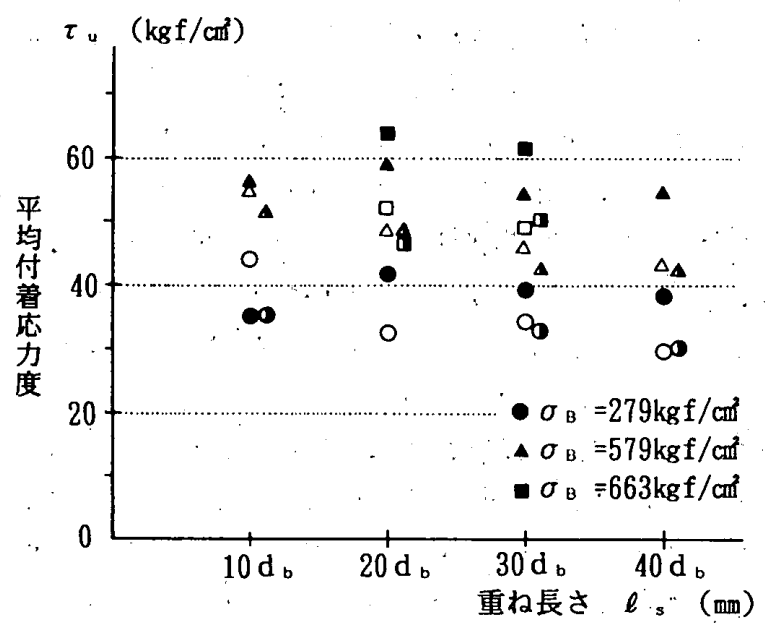

図ー- 17 . 鉄筋位置の違いによる付着割裂強度の比較 
端筋に重ね継手を設けると下端筋の場合に比べ付着割裂 強度は小さくなり、その比は普通強度の場合と同等であ ると言える。

\section{3 变形性能への各種要因の影響}

鉄筋の降伏強度を上回る継手耐力を確保した場合でも 重ね継手を有する試験体は鉄筋降伏後付着割裂破罗を生 じる場合がある。このような鉄筋降伏後付着割裂破壊す る褃験体では、強度俨価は困難であるが、変形性能の評 侕は可能である。図一 18 に破壊時のたわみ量を鉄筋降 伏時のたわみ量で除した塑性率とコンクリート強度、鉄 第強度（降伏点）、重ね長さとの関係を示すが、図より 同じ重ね長さで鉄筋強度が等しい場合にはコンクリート 䖵度が高いほど、また、コンクリート強度が等しい場合 には鉄筋強度が小さいほど、材料強度が等しい場合には 雨ね長さが長いほど塑性率が大きくなることがわかる。

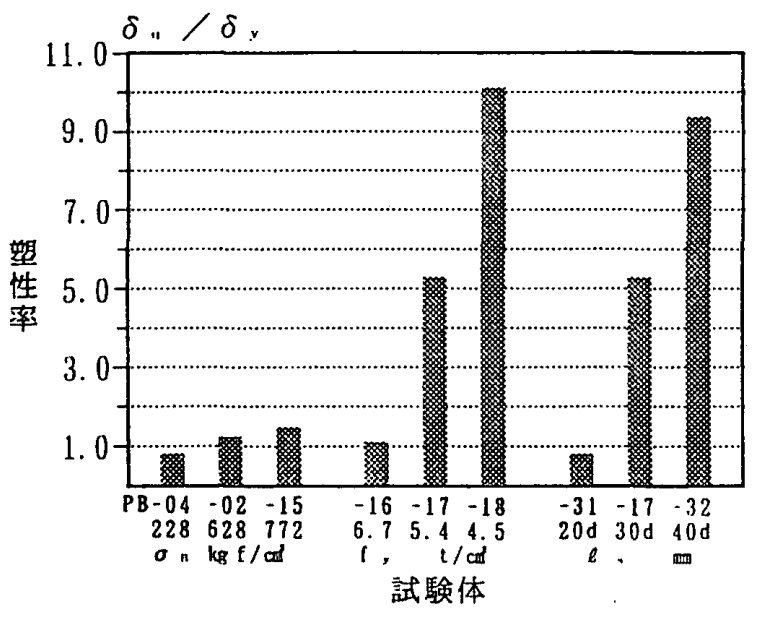

図一-18 変形性能の比皎

\section{5.まとめ}

重ね継手を有する高強度鉄筋コンクリート部材を対象 に実験を行った結果、次の結論が得られた。

（1）鉄筋応力が小さいレベルでは継手端で付着力の負 担が主に行わ机、継手部の付着応力度分布は凹型形状と なるが、破罗直前には継手部全体でほぼ一様な分布とな る。つまり、継手全体である限界の付着応力度に達した 時付着割裂破壊となると考えられる。ただし、破填直前 の付着応力度分布を詳細に見ると荷重端の付着坎力度が 逆に小さくなっており、付着性能が低下していることが わかる。また、コンクリート強度が高いほど継手端での 付着力の負担が大きくなる。

（2）継手端に曲げひびわれが集中し、その幅が大きく なると言われるが、鉄筋降伏前では継手の有無によるひ びわれ幅の差異はほとんど見られなかった。また、最大 ひびわれ蝠はコンクリート強度が高いほど小さくなる傾 问が見られた。
（3）付着割裂強度はコンクリート強度の違いにかかわ らず重ね長さが短いと大きくなり、付着割裂強度式では 重ね長さを考凰する必要がある。corner split型破壊の 場合、付着割裂強度と重衫長さの関係として、（4）から (6) 式で示す近似式が得られる。

（4）付着割裂強度はコンクリート強度が高いほど大き いが、コンクリート強度に対する増加率は補強䇽の有無 で異なる。付着割裂強度とコンクリート強度の関係とし て、補強筋の無い場合 (7) から (9)、補強筋の有る場合 (10)から(13)式で示す近似式が得られる。

（5）重ね長さやコンクリート強度の違いにかかわらず 下端筋の付着割裂強度は上端筋の場合より大きく、その 比は約1.24であった。

（6）鉄筋降伏後付着割裂破壊する場合には、その変形 性能はコンクリート強度が高いほど、鉄筋強度が小さい ほど、重ね長さが長いほど大きくなる。

\section{謝辞}

本研究の実験を行うにあたり、串木克巳氏（侏テクネ ット）、小林俊夫氏（清水建設技術研究所）の再氏に多 大なる御協力をいただきました。ここに深く感謝の意を 表します。

\section{参考文献}

1)Tepfers, R. : A Theory of Bond Applied to Overlapped Tensile Reinforcement Splices for Deformed Bars 、 Publication 73:2, Division of Concrete Structures 1973, Cha1mers University of Technology, Gutenberg, Sweden

2）田中礼治，但木幸男，大芳賀義喜：高強度鉄筋SD50の重ね継 手に関する実験的研究, 日本建築学会構造系諭文埌告集、第 405号，p. 19，1989年11月

3)角陸純一, 猿田正明：高強度鉄筋コンクリート部材の重和継 手に関する実験研究（その 1 鉄筋両引実験），日㶱建築学 会関東支部研究報告集, p. 69 , 昭和 62 年.

4)角陸純一，猿田正明: 高強度鉄箭コンクリート部材の重ね継 手に関する実験研究（その 2 はりの純曲げ実験）, 日本建 築学会大会学術講演梗概集， p. 143，昭和62年10月.

5)小林他：在来鉄筋継手を全数継手で用いる場合の継手性能評 価に関する研究（その5・重ね継手実験方法の逵いによる結 果の比較），日本建築学会大会学術講演梗概集，p4!5, 1993年 6) Orangun, C. 0. , Jirsa, J. 0. and Breen, J. E. ;A Reevaluation of Test Data on Development Length and Splices , ACI Journal, Proc. Vol. 74, p. 114, Mar. 1977

7)藤井 栄, 森田司郎：異形鉄筋の付着割裂強度に関する研究 一第 2 報 付着割裂強度算定式の提案一, 日本建築学会構造 系論文埌告集、第 324 号，p. 45 ，昭和58年 2 月

8)藤井 采, 森田司郎 : 異形鉄筋の付着割裂強度に関する研究 一第 1 報 付着割裂破壊を支配する要因についての実験結果, 日本建築学会構造系論文報告集、第 324 号, p. 45 , 昭和 58 年 2月

（1992 年 12 月 25 日原稿受理，1993 年 8 月 25 日採用決定） 